\title{
Long-term cytotoxic effects of contemporary root canal sealers
}

\author{
Emmanuel João Nogueira Leal da SILVA', Carolina Carvalho SANTOS ${ }^{1}$, Alexandre Augusto ZAIA ${ }^{2}$
}

1- DDS, MSc, PhD student, Piracicaba Dental School, University of Campinas, Piracicaba, SP, Brazil.

2- DDS, MSc, PhD, Adjunct Professor Endodontics Department Piracicaba Dental School, University of Campinas, Piracicaba, SP, Brazil.

Corresponding address: Dr. Emmanuel João Nogueira Leal da Silva - Rua Herotides de Oliveira, 61/902 - Niterói - RJ - Brasil - 24230230 - e-mail: nogueiraemmanuel@hotmail.com - Phone: (55) 2183575757 - Fax: (55) 2126108439

Submitted: April 4, 2012 - Modified: January 6, 2013 - Accepted: January 7, 2013

\section{ABSTRACT}

\begin{abstract}
$\mathrm{O}$ bjectives: The aim of the present study was to investigate the effects of root canal sealers on the cytotoxicity of 3T3 fibroblasts during a period of 5 weeks. Material and Methods: Fibroblasts $\left(3 \mathrm{~T} 3,1 \times 10^{5}\right.$ cells per well) were incubated with elutes of fresh specimens from eight root canal sealers (AH Plus, Epiphany, Endomethasone N, EndoREZ, MTA Fillapex, Pulp Canal Sealer EWT, RoekoSeal and Sealapex) and with elutes of the same specimens for 5 succeeding weeks after immersing in simulated body fluid. The cytotoxicity of all root canal sealers was determined using the MTT assay. Data were analyzed using ANOVA and Tukey's test. Results: RoekoSeal was the only sealer that did not show any cytotoxic effects $(p<0.05)$. All the other tested sealers exhibited severe toxicity initially (week 0). MTA Fillapex remained moderately cytotoxic after the end of experimental period. Toxicity of the other tested sealers decreased gradually over time. The evaluated root canal sealers presented varying degrees of cytotoxicity, mainly in fresh mode. Conclusions: RoekoSeal had no cytotoxic effect both freshly mixed and in the other tested time points. MTA Fillapex was associated with significantly less cell viability when compared to the other tested root canal sealers.
\end{abstract}

Key words: Cell survival. Cultured cells. Fibroblasts. Root canal sealants.

\section{INTRODUCTION}

A complete sealing of the root canal system after cleaning and shaping is critical for a successful endodontic treatment ${ }^{20}$. Root canals are traditionally filled with gutta-percha cones and a root canal sealer. Although endodontic sealers are designed to be used only within the root canal during endodontic therapy, sometimes they can extrude through the apical constriction ${ }^{13,16}$. Indeed, they are often placed in intimate contact with the periapical tissues for an extended period of time ${ }^{12,16}$. Thus, the biocompatibility of root canal sealers is an important factor when choosing the best material.

The currently used sealers are based on zinc oxideeugenol, calcium hydroxide, polydimethylsiloxane, silicone, epoxy resin and methacrylate resin. They exhibit a variable degree of cytotoxicity depending on the conditions under which testing was performed ${ }^{5,6}$. Most of these sealers exert some toxic effect when they are fresh or in short testing times $2,5,6,21,22$. However, these intervals are probably inadequate to predict the biological response of sealers, which may remain in contact with periapical tissues for decades. Only a few studies have attempted to evaluate the longitudinal cytotoxicity effects of root canal sealers $1,2,14,21$.

Whereas the cytotoxicity of conventional endodontic sealers is well documented ${ }^{1,2,6,14,15,21}$, little is known about the long-term toxicity of newer endodontic sealers, such as Epiphany, RoekoSeal and MTA Fillapex. Previous reports have shown variable results ${ }^{9,11,12,19}$, so it is of interest to compare new and old sealers by standardized cell culture methods in the same investigation. Long-term tests provide a more extensive toxicity profile that would be useful to determine the clinical performance of root canal sealers. Therefore, the aim of this study was to evaluate the cytotoxicity of eight root canal sealers over long periods of analysis. 


\section{MATERIAL AND METHODS}

\section{Sample and extract preparation}

Eight root canal sealers were evaluated: $\mathrm{AH}$ Plus, Endomethasone N, EndoRez, Epiphany, MTA Fillapex, Pulp Canal Sealer EWT, RoekoSeal and Sealapex. The tested materials, product names, manufacturers and components are listed in Figure 1.

The sealers were mixed according to the manufacturers' instructions. Nine discs of each sealer were fabricated under aseptic conditions in sterile cylindrical Teflon blocks with $5 \mathrm{~mm}$ in diameter and $2 \mathrm{~mm}$ in height. Excess material was removed with a sterile scalpel and the sealers were carefully removed from Teflon blocks after $1 \mathrm{~h}$. Cytotoxicity of the sealers was assessed immediately after mixing and for 5 succeeding weeks (weeks 1-5). The extraction was made eluting the sealers in cell culture medium using the surface area-to-volume ratio of approximately 150 $\mathrm{mm}^{2} / \mathrm{mL}$ between the surface of the samples and the volume of medium ${ }^{10}$. The extraction vials were agitated for $24 \mathrm{~h}$ in water at $37^{\circ} \mathrm{C}$. Between tests, the specimens were aseptically removed and rinsed twice with sterile simulated body fluid (SBF) as previously reported ${ }^{1,15}$. Control samples containing only culture medium were similarly treated.
Undiluted extracts were used for the testing.

\section{Cytotoxicity assay}

Balb/c 3T3 cells (American Tissue Type Collection, ATCC, Manassas, VA, USA) were cultured in Dulbecco's Modified Eagle Medium (DMEM) (Gibco, Invitrogen Grand Island, NY, USA) supplemented with $10 \%$ fetal bovine serum (FBS) (Sigma-Aldrich, Sigma Chemical Co, St Louis, MO, USA), 100 mg/ $\mathrm{mL}$ of streptomycin, $100 \mathrm{mg} / \mathrm{mL}$ of penicillin at $37^{\circ} \mathrm{C}$ in a humidified incubator containing $5 \% \mathrm{CO}_{2}$. Confluent cells were detached with $0.25 \%$ trypsin and $0.05 \%$ ethylenediaminetetraacetic acid (EDTA) for $5 \mathrm{~min}$, and aliquots of separated cells were subcultured. Cells were seeded in 24-well plates $\left(1 \times 10^{5}\right.$ cell/well). After overnight attachment, cells were exposed to the extracts of the different tested sealers (500 $\mu \mathrm{L} /$ well). Cytotoxicity testing was repeated immediately after mixing (fresh), and then after $1,2,3,4$ and 5 weeks to study temporal trends in cytotoxicity of the sealers.

Cell viability was determined each week (1-5 weeks) by the MTT assay: 3-(4,5-dimethylthiazol2-yl)-2,5-diphenyl tetrazolium bromide (MTT). After the removal of culture medium from each well, the cells were gently washed with $1.0 \mathrm{~mL}$ of phosphate-buffered saline. The wash was replaced with a $1 \mathrm{mg} / \mathrm{mL}$ MTT-succinate solution (Sigma-

\begin{tabular}{|c|c|c|}
\hline Root Canal Sealer & \multicolumn{2}{|c|}{ Components } \\
\hline AH Plus, Dentsply, Germany & $\begin{array}{l}\text { Paste A: Epoxy Resins, Calcium } \\
\text { Tungstate, Zirconium Oxide, Silica, } \\
\text { Iron Oxide Pigments, Aerosil }\end{array}$ & $\begin{array}{c}\text { Paste B: Adamantane amine, N,N- } \\
\text { Dibenzyl-5-oxanonane, TCD-Diamine, } \\
\text { Calcium Tungstate, Zirconium Oxide, } \\
\text { Aerosil }\end{array}$ \\
\hline Epiphany, Pentron, USA & $\begin{array}{l}\text { BisGMA, UDMA, Hydrophilic } \\
\text { Methacrylates }\end{array}$ & \\
\hline Endomethasone N, Septodont, France & $\begin{array}{c}\text { Powder: Hydrocortisone Acetate, } \\
\text { Thymol lodide, Barium Sulphate, Zinc } \\
\text { Oxide, Magnesium Stearate }\end{array}$ & Liquid: Eugenol \\
\hline EndoREZ, Ultradent, USA & $\begin{array}{l}30 \% \text { UDMA, Zinc Oxide, Barium } \\
\text { Sulphate, Resins, Pigments }\end{array}$ & \\
\hline MTA Fillapex, Angelus, Brazil & $\begin{array}{c}\text { Salicylate Resin, Diluting Resin, } \\
\text { Natural Resin, Bismuth Trioxide, } \\
\text { Nanoparticulated Silica, MTA, } \\
\text { Pigments }\end{array}$ & \\
\hline $\begin{array}{l}\text { Pulp Canal Sealer EWT, SybronEndo, } \\
\text { USA }\end{array}$ & $\begin{array}{l}\text { Powder: Silver Powder, Zinc Oxide, } \\
\text { Thymol lodide, Dimeric Acid Resin }\end{array}$ & Liquid: Clove Oil, Canada Balsam \\
\hline RoekoSeal, Coltene, Germany & $\begin{array}{c}\text { Polymethylsiloxane, Silicone Oil, } \\
\text { Paraffin-base Oil, Hexachloroplatinic } \\
\text { Acid, Zirconium Dioxide }\end{array}$ & \\
\hline Sealapex, SybronEndo, USA & $\begin{array}{c}\text { Paste A: Isobutyl Salicylate Resin, } \\
\text { Silicon Dioxide, Bismuth Trioxide, } \\
\text { Titanium Dioxide Pigment }\end{array}$ & $\begin{array}{c}\text { Paste B: N-ethyl Toluene Solfanamide } \\
\text { Resin, Silicon Dioxide, Zinc Oxide, } \\
\text { Calcium Oxide }\end{array}$ \\
\hline
\end{tabular}

Figure 1- Composition of materials and their manufactures 
Aldrich) for $4 \mathrm{~h}$. After aspiration of the solution, the cell monolayers were rinsed with doubledistilled water. Then the water was completely removed. Formazan crystals produced within the cells by succinate dehydrogenase (SDH) reduction of MTT were dissolved using destaining solution (isopropanol-10\%NP40-0.4N HCl). Aliquots (100 $\mu \mathrm{L}$ ) of the solution were then transferred from each well to a 96-well plate and the absorbance was measured at $490 \mathrm{~nm}$ using a microplate reader (Hitachi, Tokyo, Japan). The formazan content of each well was computed as a percent of the control group (untreated cells). Cytotoxicity responses were rated as severe (30\%), moderate (30-60\%), mild (60-90\%) or noncytotoxic $(>90 \%)^{8}$.

\section{Data and statistical analysis}

All assays were repeated three times to ensure reproducibility. Toxicity of the endodontic sealers was assessed by measuring cell viability that had been determined by SDH activity (MTT assay). Data were analyzed by one-way analysis of variance (ANOVA), and follow-up comparison between the groups was made using Tukey multiple-comparison test (at 95\% confidence interval level, $\alpha=0.05$ ). Data were analyzed using the statistical software SPSS $^{\circledR}$ (SPSS; IBM, Chicago, IL, USA).

\section{RESULTS}

The results of the MTT assay over all the time periods are shown in Table 1 and collectively represented in Figure 2. RoekoSeal was the only sealer that did not show any cytotoxic effects in any time point and was not significantly different from the control $(p<0.05)$. The other sealers showed some toxic effects when they were evaluated in fresh conditions. After 1 week, Endomethasone N and Pulp Canal Sealer EWT became noncytotoxic with no statistically significant difference from the

Table 1- Succinate dehydrogenase activities exhibited by 3T3 cells in the presence of different root canal sealers

\begin{tabular}{ccccccc}
\hline Materials & Fresh & Week 1 & Week 2 & Week 3 & Week 4 & Week 5 \\
\hline Control & $100^{\mathrm{A}, 1}$ & $100^{\mathrm{A}, 1}$ & $100^{\mathrm{A}, 1}$ & $100^{\mathrm{A}, 1}$ & $100^{\mathrm{A}, 1}$ & $100^{\mathrm{A}, 1}$ \\
AH Plus & $33.9^{\mathrm{D}, 3}( \pm 4.6)$ & $67.0^{\mathrm{C}, 2}( \pm 5.3)$ & $91.7^{\mathrm{AB}, 1}( \pm 5.3)$ & $95.4^{\mathrm{A}, 1}( \pm 8.2)$ & $95.8^{\mathrm{A}, 1}( \pm 6.0)$ & $99.1^{\mathrm{A}, 1}( \pm 6.3)$ \\
Endomethasone N & $48.2^{\mathrm{C}, 2}( \pm 3.8)$ & $95.1^{\mathrm{AB}, 1}( \pm 6.4)$ & $96.4^{\mathrm{A}, 1}( \pm 6.3)$ & $100.4^{\mathrm{A}, 1}( \pm 15.4)$ & $100.0^{\mathrm{A}, 1}( \pm 9.3)$ & $100.3^{\mathrm{A}, 1}( \pm 7.6)$ \\
EndoREZ & $12.4^{\mathrm{E}, 4}( \pm 5.7)$ & $44.8^{\mathrm{D}, 3}( \pm 7.9)$ & $73.0^{\mathrm{C}, 2}( \pm 12.3)$ & $78.1^{\mathrm{B}, 2}( \pm 13.6)$ & $84.9^{\mathrm{AB}, 1}( \pm 10.9)$ & $93.5^{\mathrm{A}, 1}( \pm 13.2)$ \\
\hline Epiphany & $7.5^{\mathrm{E}, 5}( \pm 4.4)$ & $36.8^{\mathrm{D}, 4}( \pm 2.5)$ & $52.1^{\mathrm{D}, 3}( \pm 8.7)$ & $66.7^{\mathrm{B}, 2}( \pm 12.4)$ & $70.8^{\mathrm{B}, 2}( \pm 9.6)$ & $91.3^{\mathrm{A}, 1}( \pm 12.6)$ \\
MTA Fillapex & $5.0^{\mathrm{E}, 4}( \pm 3.4)$ & $13.4^{\mathrm{E}, 3}( \pm 4.7)$ & $15.3^{\mathrm{E}, 3}( \pm 1.0)$ & $19.7^{\mathrm{C}, 3}( \pm 4.3)$ & $34.0^{\mathrm{C}, 2}( \pm 5.9)$ & $57.3^{\mathrm{B}, 1}( \pm 13.4)$ \\
\hline Pulp Canal Sealer & $47.3^{\mathrm{C}, 2}( \pm 3.7)$ & $92.4 \mathrm{~A}^{\mathrm{B}, 1}( \pm 11.3)$ & $97.7^{\mathrm{A}, 1}( \pm 12.2)$ & $100.5^{\mathrm{A}, 1}( \pm 12.9)$ & $100.1^{\mathrm{A}, 1}( \pm 13.6)$ & $100.3^{\mathrm{A}, 1}( \pm 13.4)$ \\
EWT & & & & & & \\
RoekoSeal & $93.7^{\mathrm{A}, 1}( \pm 10.1)$ & $97.3^{\mathrm{A}, 1}( \pm 7.0)$ & $100.7^{\mathrm{A}, 1}( \pm 4.0)$ & $99.1^{\mathrm{A}, 1}( \pm 5.5)$ & $100.4^{\mathrm{A}, 1}( \pm 12.0)$ & $100.2^{\mathrm{A}, 1}( \pm 11.9)$ \\
\hline Sealapex & $66.0^{\mathrm{B}, 3}( \pm 9.7)$ & $85.4^{\mathrm{B}, 2}( \pm 3.5)$ & $82.7^{\mathrm{BC}, 2}( \pm 3.4)$ & $90.5^{\mathrm{AB}, 1}( \pm 4.2)$ & $93.6^{\mathrm{A}, 1}( \pm 11.8)$ & $98.9^{\mathrm{A}, 1}( \pm 9.8)$ \\
\hline
\end{tabular}

The data are normalized against the control group. Values represent means (standard deviations) and are expressed as relative percentages of the succinate dehydrogenase $(\mathrm{SDH})$ activity of the control group (100\%). For each column, data with different letter superscripts denote significant difference $(p<0.05)$. For each row, data with different numerical superscripts denote significant difference $(p<0.05)$

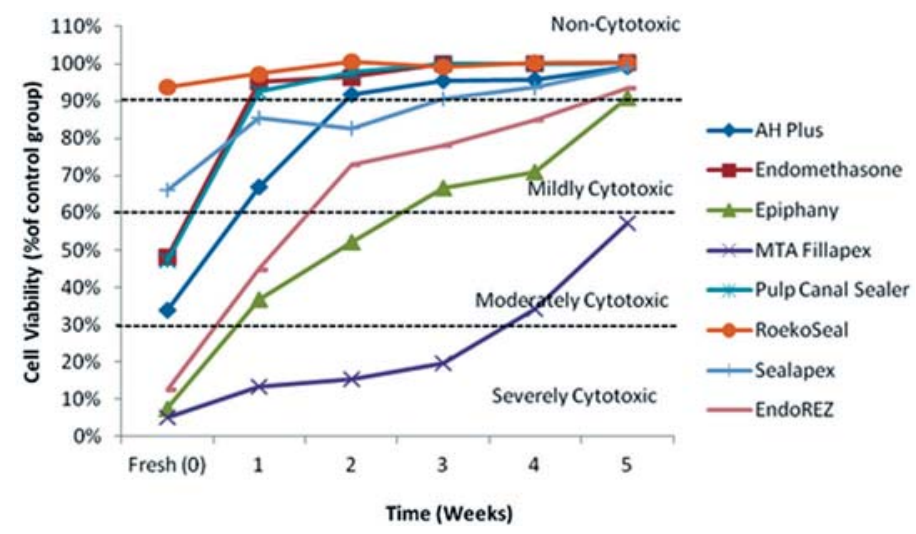

Figure 2- Line chart depicting the changes in cell viability over time after the eight endodontic sealers were repeatedly immersed in a simulated body fluid. Values are expressed as percentages relative to the control group and classified as severe $(<30 \%)$, moderate $(<60 \%)$, mild $(60-90 \%)$ or non-cytotoxic $(>90 \%)$ 
control group or RoekoSeal $(p<0.05)$. Fresh AH Plus was moderately cytotoxic, it was mildly cytotoxic after 1 week and become noncytotoxic after 2 weeks. Fresh Sealapex was mildly cytotoxic and became noncytotoxic after three weeks. EndoREZ and Epiphany exhibited significant increases in the SDH activity over time ( $p<0.05$, Table 1$)$ and after 5 weeks both became noncytotoxic. Conversely, MTA Fillapex remained severely and mildly cytotoxic over the entire experimental period. At the end of the fifth week, this sealer exhibited a toxicity level that was significantly more severe $(p<0.05)$ than the other tested sealers, which became noncytotoxic.

\section{DISCUSSION}

Root canal sealers should be biocompatible since they may get in intimate contact with the periapical tissues for an extended period of time. The direct contact and the degradation of sealers over time could induce cytotoxic damage to cells and tissues and adversely affect the outcome of the root canal treatment $12,13,16,25$. This study was designed to determine the longitudinal cytotoxicity behavior of eight contemporary endodontic sealers on fibroblasts. Although cytotoxicity testing of freshly mixed sealers is relevant as they are placed into the root canal system in a freshly mixed and incompletely polymerized stage, it is important to evaluate sealers over extended periods after setting because it is likely that, during some time after clinical application, changes in cytotoxicity levels may be observed after diffusion of toxic components from the materials into the surrounding environment. This could be confirmed as all tested sealers showed different degrees of toxicity reduction after repeated testing at extended time periods.

The long-term evaluation is also more advantageous than previous strategies that assessed cytotoxicity for a shorter period because it enables establishing the peculiar toxicity profiles that are characteristic of each sealer. RoekoSeal was the only sealer that did not exhibit cytotoxic effects both freshly mixed and in the other tested time points. RoekoSeal is a silicone-based sealer, which is described as a biocompatible material ${ }^{18}$. The findings of the present study agree with several previous studies that showed that RoekoSeal was only little cytotoxic or completely non-cytotoxic even in fresh conditions ${ }^{9,11,12,21}$. The relatively severe and mild cytotoxic responses exhibited by the other sealers in fresh conditions, confirm the results reported in previous studies $2,7,9,11,12,18,22,23$. This could be attributed to the release of small amounts of toxic substances present in the sealers. Probably as a result of the diminished leaching of these toxic substances, the cytotoxicity of the tested sealers decreased in the aged specimens. Previous reports with different methodologies showed similar cytotoxic reduction after 5 weeks ${ }^{1,15,18}$.

MTA Fillapex was developed in an attempt to combine the physicochemical properties of an endodontic sealer with the excellent biological properties of MTA. According to the present results, MTA Fillapex showed a severe cytotoxicity when cells were exposed to the fresh elute of the sealer. This toxicity did not decrease over time. A longer period may then be required before the sealer can be rendered non-cytotoxic. The findings of the present study confirmed those previous studies in which strongly affected cell viability by MTA Fillapex was observed using several methodologies ${ }^{4,19}$. The results suggest correlations between the components, such as salicylate resin, diluting resin and silica with the cytotoxic effects.

Although the relevance of in vitro toxicity assays to clinical conditions has been frequently questioned, it appears that the biological risks of endodontic sealers is relatively high, as the components of various root canal sealers may induce potential tissue toxicity, leading to apical periodontal tissue damage and inflammatory responses ${ }^{6,24}$. Unfortunately these materials might remain in close contact with periapical tissues for long periods. Even in cases where the sealer does not reach directly the periapical region, there is always the possibility of elutable substances or degradation products from root canal fillings leaching through the dentinal tubules, lateral and accessory canals or apical foramina ${ }^{3}$. However, according to the results of this study, after 5 weeks, endodontic sealers exhibited non-cytotoxic effects to 3 T3 fibroblast cells reflecting no long-term risk for adverse effects. So, despite the transitory irritability that endodontic sealers may cause to periapical tissues, endodontists should evaluate the advantages and disadvantages of sealer extrusion since the unsealed remaining areas in the apical region may serve as microorganism niches, initiating or perpetuating an endodontic failure ${ }^{17}$.

\section{CONCLUSION}

The evaluated root canal sealers presented varying degrees of cytotoxicity, mainly in fresh conditions. RoekoSeal had no cytotoxic effect both freshly mixed and at the other tested time points. MTA Fillapex was associated with significantly less cell viability when compared with the other tested root canal sealers. 


\section{REFERENCES}

1- Ames JM, Loushine RJ, Babb BR, Bryan TE, Lockwood PE, Sui M, et al. Contemporary methacrylate resin-based root canal sealers exhibit different degrees of ex vivo cytotoxicity when cured in their self-cured mode. J Endod. 2009;35:225-8.

2- Araki K, Suda H, Spångberg LS. Indirect longitudinal cytotoxicity of root canal sealers on L929 cells and human periodontal ligament fibroblasts. J Endod. 1994;20:67-70.

3- Bernáth M, Szabó J. Tissue reaction initiated by different sealers. Int Endod J. 2003;36:256-61.

4- Bin CV, Valera MC, Camargo SE, Rabelo SB, Silva GO, Balducci I, et al. Cytotoxicity and genotoxicity of root canal sealers based on mineral trioxide aggregate. J Endod. 2012;38:495-500.

5- Brackett MG, Marshall A, Lockwood PE, Lewis JB, Messer RL, Bouillaguet $S$, et al. Inflammatory suppression by endodontic sealers after aging 12 weeks in vitro. J Biomed Mat Res Part B: Appl Biomat. 2009;91:839-44.

6- Bratel J, Jontell M, Dahlgren U, Bergenholtz G. Effects of root canal sealers on immunocompetent cells in vitro and in vivo. Int Endod J. 1998;31:178-88.

7- Correa GT, Veranio GA, Silva LE, Hirata R Jr, Coil JM, Scelza MF. Cytotoxicity evaluation of two root canal sealers and a commercial calcium hydroxide paste on THP1 cell line by Trypan Blue assay. ] Appl Oral Sci. 2009;17:457-61.

8- Dahl JE, Frangou-Polyzois MJ, Polyzois GL. In vitro biocompatibility of denture relining materials. Gerodontology. 2006;23:17-22.

9- Eldeniz AU, Mustafa K, Ørstavik D, Dahl JE. Cytotoxicity of new resin-, calcium hydroxide- and silicone-based root canal sealers on fibroblasts derived from human gingiva and L929 cell lines. Int Endod J. 2007;40:329-37.

10- International Organization for Standardization. ISO 109935: Biological evaluation of medical devices, part 5: tests for cytotoxicity: in vitro models. $1^{\text {st }}$ edition. Geneva: ISO; 1997.

11- Karapinar-Kazandağ M, Bayrak OF, Yalvaç ME, Ersev H, Tanalp J, Sahin F et al. Cytotoxicity of 5 endodontic sealers on L929 cell line and human dental pulp cells. Int Endod J. 2011;44:626-34. 12- Lodiene G, Morisbak E, Bruzell E, Orstavik D. Toxicity evaluation of root canal sealers in vitro. Int Endod J. 2008;41:72-7. 13- López-López J, Estrugo-Devesa A, Jané-Salas E, Segura-Egea JJ. Inferior alverolar nerve injury resulting from overextension of an endodontic sealer: non-surgical management using the GABA analogue pregabalin. Int Endod J. 2012;45:98-104.
14- Miletić I, Devcić N, Anić I, Borcić J, Karlović Z, Osmak M. The cytotoxicity of RoekoSeal and $\mathrm{AH}$ plus compared during different setting periods. J Endod. 2005;31:307-9.

15- Pinna L, Brackett MG, Lockwood PE, Huffman BP, Mai $\mathrm{S}$, Cotti $\mathrm{E}$, et al. In vitro cytotoxicity evaluation of a selfadhesive, methacrylate resin-based root canal sealer. J Endod. 2008;34:1085-8.

16- Ricucci D, Langeland K. Apical limit of root canal instrumentation and obturation part 2. A histological study. Int Endod J. 1998;31:394-409.

17- Ricucci D, Siqueira JF Jr. Fate of the tissue in lateral canals and apical ramifications in response to pathologic conditions and treatment procedures. J Endod. 2010;36:1-15.

18- Scelza MZ, Coil J, Alves GG. Effect of time of extraction on the biocompatibility of endodontic sealers with primary human fibroblasts. Braz Oral Res. 2012;26:424-30.

19- Scelza MZ, Linhares AB, Silva LE, Granjeiro JM, Alves GG. A multiparametric assay to compare the cytotoxicity of endodontic sealers with primary human osteoblasts. Int Endod J. 2012;45:128.

20- Schilder H. Filling root canal in three dimensions. Dent Clin North Am. 1967;11:723-44.

21- Schwarze T, Leyhausen G, Geurtsen W. Long-term cytocompatibility of various endodontic sealers using a new root canal model. J Endod. 2002;28:749-53.

22- Silva EJ, Accorsi-Mendonça T, Almeida JF, Ferraz CC, Gomes BP, Zaia AA. Evaluation of cytotoxicity and up-regulation of gelatinases in human fibroblast cells by four root canal sealers. Int Endod J. 2012;45:49-56.

23- Silva PT, Pappen FG, Souza EM, Dias JE, Bonetti-Filho I, Carlos IZ, et al. Cytotoxicity evaluation of four endodontic sealers. Braz Dent J. 2008;19:228-31.

24- Silva-Herzog D, Ramírez T, Mora J, Pozos AJ, Silva LA, Silva $R A$, et al. Preliminary study of the inflammatory response to subcutaneous implantation of three root canal sealers. Int Endod J. 2011;44:440-6.

25- Waltimo TM, Boiesen J, Eriksen HM, Ørstavik D. Clinical performance of three endodontic sealers. Oral Surg Oral Med Oral Pathol Oral Radiol Endod. 2001;92:89-92. 